\title{
UNHEARD VOICES AND COUNTER DISCOURSE, A STUDY OF THE MARCH BY E.L. DOCTOROW; WITH SPECIAL REGARDS TO ALAN SINFIELD'S THEORIES OF DISSIDENCE
}

Zohreh Ramin, University of Tehran, zramin@ut.ac.ir Sajjad Ghanbari, Ph.D. student, Alborz Campus University of Tehran, sajjadghanbari@ut.ac.ir

Abstract: There have been many texts and writings which show the resistances against dominant power and ideology. Texts offer glimpses of resistances and deviancies and their outcomes in the society. According to Foucault's theories, texts can be investigated to reveal the power relations in them and how power reacts to such deviancies. Literary texts can be viewed as sources where dominant ideologies, beliefs, opinions and ideas can be found. This can be more interesting when texts refer to an important event in history. The March is about historical event of General Sherman's march through America. Doctorow's text offers some resistances and dissidences against conventional ways of acting and behaving. But Sinfield believes that this representation of resistances in texts can show some fault-lines in power relations and create some gaps in power structures. These gaps can be considered as threat for dominant ideology. Doctorow tries to highlight such gaps in the society which he reveals in the novel. Dissidence.

Keywords: Ideology, Resistance, Dominant Power, Discourse,

\section{Introduction}

E. L. (Edgar Lawrence) Doctorow (1931- 2015), born and raised in the Bronx, was the grandson of Russian- Jewish immigrants and named, he says, after Edgar Allan Poe. His first published story was written when he was a schoolboy. At Kenyon College, in Ohio, he experienced the New Criticism, which was the cause of his attention to detail, his trust in the power of the well- made sentence, and his belief in the possible intelligence of the addressee. From Kenyon he went to Columbia University and studied drama, then he served in the American army in Germany. His first novel is a short, intense moral story, Welcome to Hard Times (1960), an anti- western made into a film starring Henry Fonda. 
His second novel, Big as Life (1966), was against the genre of science fiction. His first major novel was The Book of Daniel (1971), based on the lives and deaths in 1953 of Julius and Ethel Rosenberg who are sentenced to passing nuclear information to Soviet Union. It began as a dogged, consecutive narrative of facts. He gave up writing for a while and then he started again.

Ragtime (1975) is about a number of famous Americans and some common people, about the American Dream, about United States of America; its improvement and success, its justice and injustice. His later novels, Loon Lake (1980) with its wonderfully kinetic imagery, World's Fair (1985), Billy Bathgate (1989), The March (2005), and Andrew's Brain (2014) each interprets a distinctive world.

E. L. Doctorow's The March follows the people who accompany Sherman's army on the march through some states of America and through the Carolinas in the last year of the Civil War. There are soldiers, ex-slaves, freed refugees, Confederate deserters, a photographer and his free black assistant, an army field surgeon, and a native Georgian who volunteers as a Union nurse. The most obvious feature of the novel is the existence of historical characters. They coexist with fictional characters. This has lead critics to discuss the historical event of Civil War expressed in the novel and also pay much attention to historical characters.

Discussing the works of Doctorow, Linda Hutcheon in A Poetics Of Postmodernism states that "For Dante, as for Doctorow, the texts of literature and those of history are equally fair game" (124). Hutcheon places the works of Doctorow in the category of historiographic metafiction. The way which Doctorow uses to present history is discussed and Hutcheon believes that Doctorow tries to force us to rethink and reinterpret history. Hutcheon also states that Doctorow's fiction "reveals the kind of powerful impact, on both a formal and ideological level" (135) and there is not any neat distinguishing line between history and literature in his works, "and so he feels free to draw on both" (136). This style of mixing historical characters with fictional characters is the main point illustrated in Hutcheon's writing about Doctorow. It is concluded that this kind of writing can be a sign of Doctorow's mistrust in "objective presentation of history" (136).

John G. Parks also emphasizes the use of history in Doctorow's writing in "The Politics of Polyphony: The Fiction of E. L. Doctorow". He pays much attention to the blurring of the gap between fact and fiction and connects this to political views of the writer. Parks states that Doctorow is in search of " a fiction that is both politically relevant and aesthetically complex and interesting" (454-455). It shows that 
Doctorow is interested in political and social atmosphere of his own time.

Douglas Fowler also emphasizes this kind of challenging the hegemonic power in novels of Doctorow. Fowler compares Doctorow to some great writers and shows that Doctorow can be viewed as a combination of them; "Like Nabokov, prose for prose's sake is an art worth a lifetime's devotion. And like Poe, Melville, Ambrose Bierce, and Faulkner, there is a gleam of the macabre in Doctorow's created kingdoms and unsettling taste for terror and blood" (6).

Terror and blood are constituent parts of any war. Writing about war also is to include them and show such scenes. As The March is about civil war in the United States, most of the critics pay so much attention to the connection of this novel and that historical event. As it is discussed, most of the writings about Doctorow's novel try to find the relationship between history and fiction in his works. There is not any significant criticism about the society and people which Doctorow gives them space to articulate their ideas and show their existence in the novels. The reason of Doctorow's selection of the civil war and the style which he uses to write about war is not discussed. Doctorow places the emphasis of his novel, The March, on ordinary people who are non-combatant ones. The march of General Sherman through America is the source of The March, but the battle's influences on ordinary people, freed slaves, women, children and blacks are presented in most of the pages.

Seeking protection in their proximity to Union forces, ex-bonds people follow Sherman's army in pursuit the freedom they have recently claimed for themselves. The freed people's presence represents the march as an opportunity to realize the nation's highest principles, but a loss of morality and humanity can be viewed during military campaigns and in battle fields, a descent into "mindless mass rage severed from any cause, ideal or moral principle" (Doctorow 298). While The March scarcely shows battles between two fighting armies, violence and murder is often committed against prisoners, noncombatants and ordinary people. As former slaves are to find their own freedom, some instances of soldiers changing allegiances and uniforms reflect the larger problem of the nation.

Doctorow turns his attention to the Civil War to show his interest in the idea of a society transformed and by the reality that for civilian refugees, particularly ex-slaves, the best hope of security lay with the massive moving force of Sherman's army. These refugees and slaves try to find security beside dominant power. The way which is used by Doctorow to reveal dominant power and its ideas and opinions 
are discussed in this paper and it tries to highlight the resistances and dissidences against dominant power which is done by some of the slaves, ordinary people and blacks in the novel. According to theories of Foucault regarding discourse Doctorow's novel is studied to show the discourse which he presents and it is compared to the discourse which is favored by dominant ideology. Thorough the discourse presented in The March some unheard voices gain opportunities to express themselves and the resisting voices presented in the novel are studied according to Sinfield's theories.

\section{Ex-slaves or Ever-slaves}

Foucault opens a new scope to the realm of literary studies in his works; The History of Sexuality (1978), Power/Knowledge (1980), The Birth of the Clinic (1973) and Discipline and Punish (1977). He emphasizes on the function and condition of texts in power relations, on the position of subjectivity within literary writings, and on the contest for meaning and control of meaning in the reception and criticism of literary texts. His studies have led to a close attention to the effects and functions of literature in history, and to how literature plays a key role in constructing a society's sense of itself. The degrees to which literature participates in forming the dominant ideological assumptions of a given time can be examined through studying texts closely and with regard to their impacts and functions in society.

The dominant ideological assumptions of any time impose some ideas, opinions, beliefs and ways of thinking and living on any individual and any citizen. In The March, some characters are presented that they have accepted the ideological assumptions of their time. These are characters who have internalized the ideological beliefs and ideas of society. They think that every individual should be subordinate to dominant power and there should not be any deviation or resistances against power's will. People should adjust themselves to social norms and disciplines according to this kind of thinking. This can be easily seen in the way that some of freed slaves in The March behave and act through the novel. They are confused and do not know what to do after being freed; "He himself stood in the middle of the road with his staff and did not move" (Doctorow 9). Doctorow illustrates that most of the slaves do not have any clear idea of being free and do not ever think of living as an independent individual. Living all their life as slaves have made them internalize such codes of behavior and most of them are unable to think against what they have been offered as their common lifestyle. 
Doctorow also reveals a character who breaks these codes and regulations. There is a little boy, David, who chooses to be free, to make decision for his own life while other slaves are unable to handle the situation. It is said in the novel that his behavior, escaping from the plantation where slaves are held, is something "beyond the capacity of most of the slaves on that plantation" (Doctorow 225). It is shown that the only one who is willing to change his life is David, the little boy, who has not internalized the ways of being a slave; "With his dash from the house the child had asserted his life to be his own. It did not have to be more than a moment's impulse, but it was enough to set him free" (225). One important issue regarding David is that he is eight or nine years old. It signifies that he has not internalized norms and regulations completely. Although the slaves are freed from the plantation but this freedom is just physically and they are not able to think independently and free themselves mentally except David. They are ex-slaves but the story reveals that they cannot make significant decision and they still behave like slaves and do not show any characteristics of freed people. They act as if they are to be slaves all their life. It is probably because of the power of dominant ideology which has created such an atmosphere to make people obedient subjects. Doctorow's portrayal of this sort of activities by slaves can reveal the powerful impact that dominant ideology has upon people.

\section{The place of slaves, negroes and women in society}

Ideology is defined as something which is connected to society by Althusser in his work, For Marx; that is, ideology is clearly related to the practices by institutions in society. It is mentioned that ideology forms the individual's awareness and creates the person's understanding and recognition of experiences and events. He states that people have to live in a set of shaping conditions, but they usually do not understand their relationship to actual conditions except through ideology. Althusser views ideology in a different way from those before him and gives it some new features:

The meaning of this whole, of a particular ideology (in this case an individual's thought), depends not on its relation to a truth other than itself but on its relation to the existing ideological field and on the social problems and social structure which sustain the ideology and are reflected in it; the sense of the development of a particular ideology depends not on the relation of this development to its origins or its end, considered as its truth, but to the relation found within this development between the mutations of the particular ideology and the 
mutations in the ideological field and the social problems and relations that sustain it $(62,63)$.

Ideology shapes and decides about any relationship among community members. It is a part and a constituent part of any society and acts through many institutions and organizations in community; that is, the ideology dictates its own principles and codes through various institutions within the framework of every society. These institutions are to be considered as vehicles of ideology. Schools, universities, educational centers, clinics, hospitals and army are among chief institutions of every society. They provide the intellectual and ideological foods for members of society although these places are considered to produce truths and facts. Foucault through his career, in works such as The History of Sexuality (1978), Power/Knowledge (1980), The Birth of the Clinic (1973) and Discipline and Punish (1977), studies impacts of different institutions on people and the role that those people play in sustaining or resisting these effects. These institutions work upon people in such a way that they become the subjects of power relations. The institutions do this by the use of some regulations and disciplines. These regulations affect the people's views and beliefs.

People's beliefs and views are clearly revealed in the course of the novel by Doctorow. Through the little girl, Pearl, who is a daughter of a woman slave and a landowner, Doctorow explains that even the father does not accept her as his own daughter because of a mother who is a slave. This sort of view is present in much of the expressions concerning slaves. This belief that the salves are to be viewed as miserable and lower people in the society is held by most of the characters. Beside this, most of the slaves have accepted themselves as being inferior and more than that they are always in search of somebody as a superior. The author discusses the existence of slavery and views and beliefs about them throughout the novel clearly. Even the generals and armies who are there to bring freedom and equality to people ignore this part of the society; "As they rode onto the grounds he (General Clarke Had) immediately saw, and ignored, the slaves standing there" (Doctorow 10). They are the ones who are ignored, whose voices are unheard and whose freedom is blurred.

Seeking freedom is an important matter expressing about Peral, a slave girl. She has to hide many things to be able to find freedom. She should conceal the fact that she is a girl to be able to move with armies. Doctorow reveals this kind of disguise to show that there is not any equality concerning the gender. The women are also viewed as inferior ones. Being a slave girl is also hidden by Peral. This is 
because of people's opinions about slaves which is discussed before. More than this she tries not to be viewed as a negro. Negros are not treated fair in the society of the novel as it is expressed by Doctorow; "Yes, he thought, if the South were to prevail, theoretically there could be a time when whiteness alone would not guarantee the identity of a free man" (188). This obviously reveals that dominant discourse is against blacks and negroes. Even General Sherman who is one of top officials expresses the similar thoughts when he encounters some black people. He mutters with himself; " To catechize these blacks regarding my character! How would any of them be here if not for me? Ten thousand are free and fed and clothed by my orders! That they are not fighting is my best military judgment. Nor have I had the leisure to train them" (119). The best military decision is not related to winning the war or choosing the best strategy but it is preventing these people from fighting. This kind of discourse regarding blacks, negroes, slaves and women are prevalent in the course of the story.

\section{Dominant power and Doctorow's attitude}

A discourse can be viewed as some statements and utterances which combine with others in particular ways. Discourse is linked to some rules and regulations which are vital in distribution and circulation of certain utterances and statements. Some statements can be circulated widely and others will find limited circulation. Foucault pays much attention to the concept of exclusion. He does not see discourse just as a set of statements and utterances which have some coherence, he believes that a discourse exists because of a complex set of practices which try to circulate it and other practices which try to fence discourse off from others. Foucault in "The Order of Discourse" and "The Subject and Power" expresses the view that truth can be something which has support from a whole range of practices and universities, clinics, government departments, scientific bodies, publishing centers, armies and so on. All of these institutions can be regarded as responsible for the exclusion of statements which they view as false and they keep in circulation those statements which they mark them as true. The circulation of discourses and statements is among main tasks of institutions and organizations. These institutions determine the exclusion of certain statements from their own discourses.

The March is about General Sherman's march in the time of civil war. Therefore, it is supposed to spread a discourse about bravery and heroism of Sherman and his troops. But Sherman is discussed a 
little and he appears without any clear statements about his characteristics and actions related to war and heroism. Nothing is said about his role and part in freeing the people and wining the civil war. Doctorow tries to bring to forth such characters as Pearl, David, Emily Thompson, Arly and Will who are among ordinary people of the society. It is clear that such people are ignored during war and also in a text which is to express war happenings. Instead of creating a passage about bravery, martyrdom and sacrifices of General Sherman and his troops, Doctorow dedicates most of the pages to people who do not play any role in the battlefield. Those are the ones who are not mentioned in any history or text about war. It is shown that they should be considered and discussed and this kind of discourse should have some space in writings about war. Linda Hutcheon puts much emphasis on this view in $A$ Poetics of Postmodernism. The characteristics of postmodern novels are mentioned and it is concluded that:

Fiction does not mirror reality; nor does it reproduce it. It cannot. There is no pretense of simplistic mimesis in historiographic metafiction. Instead, fiction is offered as another of discourses by which we construct our version of reality, and both the construction and the need for it are what are foregrounded in postmodern novel (40).

The March presents a discourse different from the typical one and tries to create its own version of reality through its own particular discourse. This type of discourse which is not included and favored by dominant discourse and it is a discourse different from it is named counter discourse by Foucault. This counter discourse gives voice to those who are ignored and excluded from dominant one.

In addition to this matter that most of the pages and much of the discourse are about ordinary people, Doctorow uses an unusual discourse about government and military officials. The army which is supposed to bring freedom and peace to people is displayed not considering ordinary people important and Doctorow reveals some instances of usurping people's properties and misuse of power by military forces. In one scene a woman is bothered and raped by some soldiers and more than that top commanders ignore this assault and do nothing about it. Beside General Sherman and his commanders who do not receive much attention, the discourse and statements about president are not ordinary and usual. The importance Doctorow places on a leader's ability to mourn, the degree of personal responsibility one feels for the loss of life, and the president's role as craftsman of the national soul suggests the importance of the presidential figure of The March. During their brief meeting, army surgeon Wrede Sartorius 
observes the comportment of Abraham Lincoln and initially likens it to the demeanor of "an elderly woman," a quality that in the doctor's estimation does not befit the presidential office. Sartorius notes Lincoln's fear of war, his dread that the Civil War will go on indefinitely, and the deference Lincoln shows subordinates (Doctorow 331). Sartorius links these qualities for weakness but eventually reconsiders his conclusions; "Mr. Lincoln's humility", Sartorius realizes, "seemed to have been like a favor to his guests, that they would not see the darkling plain where he dwelled" (334-335). According to the doctor, "The moral capacity of the President made it difficult to be in his company". Upon meeting Lincoln, Sartorius observes the president's "overdeveloped extremities," "rude features," and "terribly careworn appearance", as though they are symptoms of a "hereditary disease". The doctor surmises that a genetic condition alone could not account for the President's obvious "agony" (335). "A proper diagnosis," the doctor concludes, "was not in the realm of science. His affliction might, after all, be the wounds of the war he'd gathered into himself, the amassed miseries of this torn-apart country made incarnate"(335). These are among statements and expressions used to describe the presidential figure of the novel. It is obvious that this is not a kind of writing expected to describe the head of the government and the dominant figure of ruling class. Doctorow creates a discourse which is not in harmony with dominant one and it can be considered as a counter discourse. This is not a discourse which ruling class expects to be spread in the society.

\section{Dominant discourse and dissident voices}

Althusser states that the opinions and thoughts of the ruling class are spread by force and also through the imposition of these opinions and thoughts on those ruled. He states that societies use Ideological State Apparatuses (ISAs) to produce consensus among their members and there are also Repressive State Apparatuses (RSAs) which use repression to impose ideas and opinions. Althusser believes that ideology is "a representation of imaginary relationship of individual to their real condition of existence" (Althusser 109). For him ideology distorts reality. The March displays the significance of both apparatuses in spreading the dominant ideology in the society. There are characters who have accepted their condition and their position within the society. Most of the slaves, negroes, blacks and even women have confirmed to norms and regulations and do not act against what dominant ideology expects from them. Slaves are shown 
unable to think about a lifestyle without any superior. They are shown paralyzed and without any power to manage their own life independently. It is obvious that the power of ISAs is so strong that most of the people are submissive and obedient to codes of behavior and norms of the society. But there are some characters among them who try to change their way of life. They show some kind of attempts against norms and regulations. David and Pearl are two main characters who try to go beyond what is expected from them. They try to defeat this imaginary relationship which was imposed upon them by ISAs.

Beside Ideological State Apparatuses, there are Repressive State Apparatuses too. Military forces are there to use repression to defeat the resistances against dominant ideology. Confederate militia who are against dominant power should become confirmed and their resistance should be broken. Dissolution of that Union by means of Confederate secession would have signaled to the world that selfgovernment is unsustainable. While the novel's title succinctly conveys its narrative premise- Sherman's campaign, a civilization on the moveThe March also conjures the citizen masses who took to the streets, first in celebration of their new republic and later in protest of its alarming transformation. As well as, Doctorow presents two freed prisoners who change their allegiances easily and commit a murder. The first thing about them, is that these two, Arly and Will, are prisoners who set free to fight. Being prisoners is the clue to their deviation and non-conformity. The second thing is their escape from the battlefield and next one is changing uniform and allegiance. Arly also kills a photographer and usurps his occupation. Above all these dissidences is the unsuccessful attempt of Arly to terror General Sherman. An attack against the most important figure of the dominant power existing in the novel. Aryl's attempt to kill General and his success in getting so near to it reveals some gaps and fault-lines even in the most powerful institute of dominant power, army.

Doctorow minimizes the army's role in the liberation of bonds people. In one glaring example, the opportunistic General Kilpatrick follows the smell of stew and goes into a kitchen. There are also several former slaves. He finds the meal much to his liking. Almost as an afterthought, he turns to the frightened diners and declares, "You all are free," a fact they probably have surmised, since the owners have abandoned the main house (162). Following his superfluous announcement, Kilpatrick administers the oath of enlistment to the French Creole cook Jean-Pierre and assigns him duties as "Sargeant of the Mess" (162). In one breath, Kilpatrick imparts freedom; in the next, 
he divests it from the cook with a conscription that lacks any volition from Jean-Pierre. "All the rights and privileges" supposed to accompany the new position likely translate to none at all, as Kilpatrick presses Jean-Pierre into a new form of unfreedom, merely to indulge the general's culinary appetites. In another instance of army's behavior with ordinary people, when the woman who chases David out of the house inadvertently strikes a soldier with her whip, that blow provokes a reprisal from the soldier, whose beating escalates into a "military event", or, more accurately, a sexual assault in which several of the soldiers participate. Earlier in Columbia, a gang of Federal soldiers rape an anonymous black woman and possibly a second. One of the victims, battered and unconscious, is taken to Sartorius's dispensary where she dies of her injuries. In both accounts of sexual assaults, the soldiers' superiors are aware of the attacks but do nothing to intervene. These show a clear break in the morality which is supposed to exist among armies. It presents the lack of morality among those who are considered to be protectors of people's lives and freedom.

The willingness of commanders to permit the assaults are extreme examples of the command philosophy Lt. Clarke acknowledges early in the novel, when his troops loot and burn Fieldstone: "The best officers knew when to look aside"(11). These are examples of RSAs role in making people obedient. Doctorow reveals that although they are there to free people, the armies are those who usurp their freedom and dictate dominant ideologies upon the slaves and ordinary people.

Dominant groups have powerful influence upon every single person in the society. They are under the influence of dominant ideology and dominant culture which impose their own thoughts on people's mind. The majority of people are cultural artifacts. Clifford Geertz in The Interpretation of Cultures believes that all humans are culture dependent. Geertz defines culture as a set of controlling mean which govern behavior. Each person can be viewed in such a way that is made culturally. Each person's views on society is always particular because there is an information gap between what our body experiences and what we must recognize in order to be able to function in society. Society cannot have complete knowledge about what happens among its entire members, therefore; this gap also exists in society. When society tries to fill in this information gap, it leads to the subjectivity of history.

Sinfield rejects the idea of incorporation of resistances by the dominant discourse; he announces that Foucault in The History of Sexuality: An Introduction expresses the same idea. Foucault denies 
that "the plurality of resistances" must be "only reactions or rebounds, forming with respect to the basic domination an underside that are in the end always passive, doomed to perpetual defeat" (qtd in Sinfield 47-48). Instead, Sinfield states that resistances or deviancies make what Foucault names a reverse discourse, in other words, "deviancy returns from abjection by deploying just those terms that relegated it there in the first place" (48). The dominant discourse attempts to contain subordinate perspectives, and in order to do this, the dominant must bring the dissenting ideas into visibility. When this happens, it can be concluded that there can be no guarantee that the subordinate will conform safely to the dominant discourse. Therefore, the dominant can be always under attack by different resisting forces.

Sinfield opposes the idea of incorporation of subordinate, and states that the inter-involvement of resistance and control does not necessarily mean the co-option of the subordinate. Sinfield states that:

Deviancy returns from abjection by deploying just those terms that relegated it there in the first place. A dominant discourse cannot prevent abuse of its resources. Even a text that aspires to contain a subordinate perspective must first bring it into visibility; even to misrepresent, one must present (48).

Therefore, there can be no assurance that the dominant discourse will co-opt and contain all the deviancies and "no guarantee that the subordinate will remain in its prescribed place" (Sinfield 48) and will be under the complete influence of dominant ideology.

These lines in which we observe deviant from the dominant culture can be considered as fault-lines. According to Alan Sinfield there are always some fault-lines in the texts which demonstrate dissidences which do not confirm to the hegemony of the dominant culture.

Alan Sinfield states that textual analysis can show dissidence injected into the texts, for dissidence acts normally with reference to dominant structures. In his essay 'Reading Dissidence', he notes that dissidence "has to invoke those structures to oppose them, and therefore, can always, Ipso facto, be discovered reinscribing that which it proposes to critique" (47). Doctorow shows examples of dissident voices through the novel. There are some characters like Pearl, David, Will and Arly who resist dominant power and try to challenge it. They are passing these fault lines and are there to highlight these gaps in the society of the novel. Beside the resisting characters, the text itself can be viewed as a dissident voice in America's society. It is not there to praise and admire Sherman's march and even there is a little referring to battlefields and heroism of the armies. More than this Doctorow 
emphasizes the unseen problems and unjust behaviors happened during the civil war. Many ordinary people are killed and the ordinary people has to bear the burden of disastrous war. The civil war is a historical event which Doctorow uses it as the historical background of his work to be able to express his own ideas and opinions. Linda Hutcheon in A Poetics Of Postmodernism explains that;

The meeting of fictional characters and historical personages in the novel may also have a function in the problematizing of the nature of the subject in the sense that it foregrounds the inescapable contextualizing of the self in both history and society. All of Doctorow's fiction works to this end (84).

To reveal the harms and difficulties of war, The March is mainly about ordinary people, slaves, women, children and black people. These people are not the ones who are written about in history or texts regarding wars. But Doctorow gives voice to them and creates a discourse about these people who are not mentioned in literature of the war.

\section{Conclusion}

E. L. Doctorow is not in favor of the fiction which is just about the private life, a fiction which does not consider the social and political dimensions. In studying Doctorow's writings, it can be concluded that he tries to write a fiction that is political and aesthetically complicated and attractive. He is interested in blurring the boundaries between fact and fiction and he also attempts to display and to challenge the hegemony of discursive practices. He creates a place in which "regimes of power", as Michael Foucault expresses, can be challenged or come to visibility. According to what Todd May argues in his book, The Philosophy of Foucault, the concept of power is viewed differently by Foucault. He mentions that Foucault makes a contrast between power and violence. Violence use force to make a body do something and therefore violence erases the possibility of resistance. But Power works by influence. Therefore, Power works by inducing. Doctorow's political views are articulated in such a way to prevent the hegemony of the dominant discourse/ ideology to construct truths blurring the views of the masses. In other words, he is against establishing a monological control over sociocultural artifacts and the resulting consent on the side of masses. As it was already mentioned a monologic culture is dictatorial and absolutistic and rejects the existence and validity of the other, of difference. But on the contrary, culture which has been viewed as a 
polyphonic area of opposing voices or as a heteroglossic dialogue or conversation, to use terms from Mikhail Bakhtin and Kenneth Burke, can be regarded as the birth place of varieties of voices constituting it. It is in this sense that Doctorow's fiction attains a dialougic and polyphonic structure and as a result tries to disrupt or dismantle regimes of power and restores ignored /forgotten/unheard voices. It is this twin aim of disruption and restoration that characterizes Doctorow's own polyphonic fiction as it seeks to engage what he calls the "progression of metaphors" (Trenner 26) constituting American's civilization.

Doctorow's novels can be classified in the realm of the historical romance or Historiographic Metafiction as Linda Hutcheon states in A Poetics of Postmodernism. Accordingly, there are ideas and opinions which try to bring about social and political changes. For Doctorow, as for such critics as Michel Foucault, discourse is worldly; power exists in discourse which is subject to change and has actual impacts on social world. In this way, Doctorow challenges the power of the regime with the power of freedom as an artist. The hidden energy of this challenge lies in the discourse and the range of discursive formations negating the hegemonic rules, regulations and codes which dictate the codes of writing and thinking. It is clear that Doctorow's purpose is to reveal and challenge the hegemony of discursive practices in order to show new possibilities of opinions, ideas and actions different from what are being circulated by dominant ideology. Doctorow's fiction shows a desire to take risks and to compete the will of a culture to monopolize the truth.

Doctorow tries to display this fact that there are two different kinds of power: the power of the regime and the power of freedom. His novels, like those of other historiographic metafictionists, are to show the distinction and similarity of the power of the regime and that of freedom (Trenner 16-27). He clearly gives voices to the characters who have been completely ignored during writings about war. Doctorow tries to display the outcomes and burdens of war upon those ignored people such as blacks, negroes, women, slaves and children. Alan Sinfield completely rejects the idea of containment or cooption of dissidence voices he argues in Cultural Materialism and the Politics of Dissidence Reading that it is impossible for a story to contain all possibilities of dissidence which it brings to play. He also considers the ranges of different readings which depend not only on texts but also on conceptual framework within which the readers address a text. And the range of feasible readings depends not only on texts but on the conceptual framework within which we address it. The society which 
Doctorow presents is full of deviations and dissenting voices. Although it is shown that some of them such as Confederate soldiers are defeated, but there are also characters who stimulate different discourse from that of dominant ideology. The text can be considered as a counter discourse which is mostly about unheard and ignorant voices; those voices which are not mentioned during histories and writings of war. The March is there to highlight the gaps and failures existing in the structure of dominant discourse. Finally, the discourse which Doctorow uses is not in harmony and conformity to dominant discourse and creates a counter hegemonic discourse.

\section{References:}

Althusser, Louis. For Marx. New York: Vintage, 1970.Print.

---'Ideological State Apparatus. in Julie Revkin and Michael Ryan (eds.). Literary

Theory: An Anthology, Oxford. Blackwell Publishers, 1998. Print.

--- Lenin and Philosophy and Other Essays. London: Verso, 1971. Print.

Begley, Adam 'E.L. Doctorow' New York Observer, LexisNexis Academic, 2005. Print.

Doctorow, E. L. The March. New York:The Random House, 2005. Print.

Fowler, Douglas. Understanding E.L. Doctorow. Carolina: University of South Carolina

Press, 1992. Print.

Foucault, Michel. Discipline and Punish: The Birth of the Prison. New York: Penguin, 1977. Print.

---. Madness and Civilization: A History of Insanity in the Age of Reason.

New York:Penguin,1961. Print.

---. Power/Knowledge: Selected Interviews and Other Writings. Edited by Gordon, Colin.

New York: Pantheon Books. 1980. Print.

---. The Archaeology of Knowledge. London: Sheridan Smith, 1972. Print.

---. The Birth of the Clinic: An Archaeology of Medical. New York: Vintage, 1975. Print.

---. The History Of Sexuality. Vol. 1. New York: Vintage, 1984. Print.

---."The Order of Discourse." Untying the Text: A Post-Structuralist Reader London:

Routeledge 1981. Print. 
Geertz, Clifford. The Interpretation of Cultures. New York: Basic, 1973. Print.

May, Todd. The Philosophy of Foucault. Chesham: Acumen Publishing Limited. 2006.

Print.

Hutcheon, Linda. A Poetics Of Postmodernism. New York: Roteledge.2004. Print.

Sinfeld, Alan. Faultines: Cultural Materialism and the Politics of Dissidence Reading.

London: Oxford, 1992. Print.

---.'Reading Dissidence'. Twentieth-Century literary Theory. New York, St.

Martin's Pres,1997. Print.

Parks, John G. "The Politics of Polyphony: The Fiction of E. L. Doctorow". Twentieth

Century Literature. 37. (1991): 454-463. Print.

Trenner, Richard (ed.) E.L. Doctorow: Essays and Conversations, Princeton, NJ:

Ontario Review Press. 1983. Print.



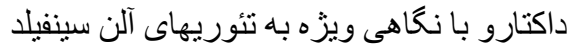

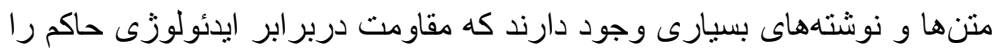



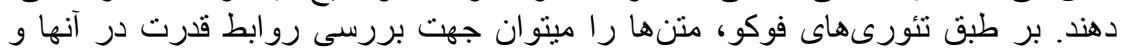

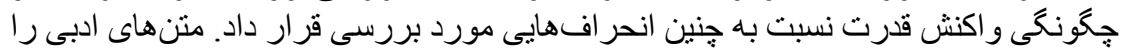



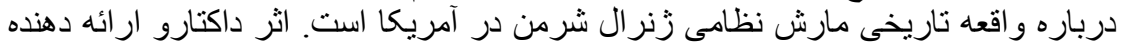

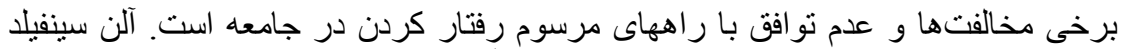

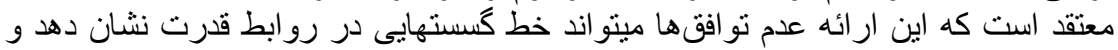



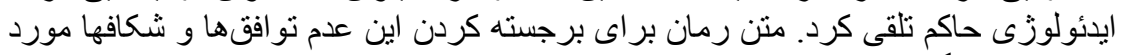
بررسى قرار كرفته شده است كرد.

كلمات كليدى: ايدئولوزى، مقاومت، عدم توافق، قدرت حاكم، كفتمان 